\title{
PROTEIN CARBONYL, OXIDATIVE STRESS, ANEMIA, TOTAL FREE AMINO ACIDS AND SHEEP HAEMONCHOSIS RELATIONSHIP
}

\section{By}

HAMDY H. KAMEL ${ }^{1}$, AL-HASSAN M. MOSTAFA ${ }^{2, *}$, MOHAMED B. AL-SALAHY ${ }^{3}$, M.S. WALAA ${ }^{1}$, and AHMAD A. WAHBA ${ }^{4}$

Department of Clinical Pathology ${ }^{1}$, Faculty of Veterinary Medicine, Beni-Suef University ${ }^{1}$, Beni-Suef, Regional Animal Health Research Laboratory ${ }^{2 *}$, Animal Health Research Institute, Assiut 71511, Department of Zoology ${ }^{3}$, Faculty of Science, Assiut University ${ }^{3}$, Assiut, Department of Parasitology ${ }^{4}$, Animal Health Research Institute,

Dokki, Giza, Egypt. ( ${ }^{\star}$ Correspondence: hassanmustafav@gmail.com fax: +20 882310339).

\begin{abstract}
The present study estimated oxidant/antioxidant status in blood of sheep naturally infested with Haemonchus contortus. Blood samples from infected and healthy (control) sheep were used to determine hematological, some antioxidants and biochemical parameters. The sheep showed microcytic hypochromic anemia. Haemonchosis in sheep resulted in a significant stimulation in MDA \& PC. By contrast, a significant inhibition of the antioxidants activity of both SOD and GSH coupled with a significant inhibition of both ceruloplasmin (CP), Total Iron (Fe) and Copper $(\mathrm{Cu})$ in infected sheep. In turn, a significant stimulation in CAT activity and in TFAA in infected sheep compared to control values was detected. The results showed a significant positive correlation between the increasing level of PC with the stimulating levels of MDA $\left(r=0.47, R^{2}=0.22\right.$, $P=0.02)$, CAT activity $\left(r=0.60, R^{2}=0.37, P=0.001\right)$, TFAA in plasma $\left(r=0.46, R^{2}=0.21, P=0.03\right)$ and EP $\left(r=0.43, R^{2}=0.19, P=0.04\right)$. By contrast, stimulated level of PC was inversely correlated with diminished values of SOD $\left(r=-0.55, R^{2}=0.31, P=0.03\right), \mathrm{Hb}\left(r=-0.43, R^{2}=0.19, P=0.04\right)$ and PCV\% ( $\left.r=-0.65, R^{2}=0.42, P=0.003\right)$. Haemonchosis was accompanied by disturbances in protein synthesis and a general oxidative damage.
\end{abstract}

Keywords: Sheep, Haemonchus contortus,; Protein carbonyl, Eosinophils; Anemia; Oxidative stress.

\section{Introduction}

Sheep are an important source of high quality food products for humans (milk and meat). Gastrointestinal nematodes are among the most destructive pathologies affecting ovine production, given the high prevalence in flocks and the serious consequences of infection. In lambs, the acute form of gastrointestinal nematode infection causes death; the more frequent, chronic form leads to notable reductions in productivity. Ruminant gastrointestinal nematode infestations are common and widespread, and their immunopathology closely resembles that of human gastrointestinal infestation. Amongst gastrointestinal nematodes of sheep, Haemonchus contortus is the predominant species (Bordoloi et al, 2012). Haemonchosis caused by $H$. contortus is the most widely distributed of the pathogenic sheep gastrointestinal nematodiasis in Egypt.
Both adult and fourth stage larvae suck blood and their migration caused haemorrhages into abomasum (Soulsby, 1982). The average blood loss due to $H$. contortus infection is $0.03 \mathrm{ml} / \mathrm{parasite} / \mathrm{day}$. Blood loss reduced feed intake, decreased body weight and wool growth (Hayat et al, 1996).

Parasitosis is a causative source of oxidative stress, indeed, several studies have reported on the presence of oxidative stress in humans and animals infected with parasites (Upcroft and Upcroft, 2001). Parasites cause inflammation when imbedding and penetrating tissues. Inflammation reactions are accompanied by generation of reactive oxygen species (Pal et al, 2005). Reactive oxygen species (ROS) include the superoxide radical $\left(\mathrm{O}_{2}\right)$, hydroxyl radical $(\mathrm{OH})$ and hydrogen peroxide $\left(\mathrm{H}_{2} \mathrm{O}_{2}\right)$. Oxidative stress occurs due to excessive production of ROS and/or impotence of enzyme and non-enzyme systems 
(Ridnour et al, 2005). Increased exposure to ROS led to cellular oxidative stress and damages of biomacromolecules (Lykkesfeldt and Svendsen, 2007).

Free radicals acted as cytotoxic agents (Gutteridge, 1995). The erythrocyte, due its role as $\mathrm{O}_{2}$ and $\mathrm{CO}_{2}$ transporter, is under constant exposure of free radicals (Harvey, 1997). However, red cells have a potent antioxidant protection that modifies free radicals into substantially less reactive intermediates (Cimen, 2008). The RBC antioxidant system primarily consists of superoxide dismutase (SOD), catalase (CAT), reduced glutathione (GSH), glutathione-peroxidase, and vitamins A, E \& C (Kurata et al, 1993). Synergistic and co-operative interactions of antioxidants rely on sequential degradation of peroxides, free radicals and mutual protections of enzymes (Gutteridge, 1995).

Lipids especially polyunsaturated fatty acids are sensitive to oxidation, leading to the term lipid peroxidation which, malondialdehyde (MDA) being abundant (Halliwell and Chirico, 1993). The accumulation of MDA in tissues or biological fluids is indicative of the extent of free radical generation, oxidative stress and tissue damage (Gutteridge, 1995). Dimitrijevi'c et al. (2012) reported that lipid peroxidation increased in sheep infected with Strongyloides papillosus.

Protein carbonyl (PC) content is actually the most general indicator and by far the most commonly used marker of protein oxidation (Beal, 2002). In mammalian system including humans that direct damage to proteins or chemical modification of amino acids in proteins during oxidative stress can give rise to protein carbonyls (Stadtman and Berlett, 1998). Oxidation of protein (protein carbonyl) included all enzymes particularly antioxidants (Stadtman et al, 1991). Excessive protein carbonyl combined with inhibitions in superoxide dismutase (SOD) and glutathione (GSH) depended on enzymatic antioxidants (Reznick and Packer, 1994). Rare data are available on protein oxidation in $H$. contortus infected sheep.
The study aimed the efficacy of sheep natural infected with haemonchosis on ROS production and resulted oxidative damages to proteins and lipids, defensive mechanism of some antioxidants on hematological and biochemical parameters. Also, it focused on correlation of PC with other parameters.

\section{Materials and Methods}

Study area: Beni-Sanad farm (El-qusya, Assiut Governorate) is located in mountainous area where the climate is continental with cold winter and hot summers. Sheep reared under natural pasture resources that grown in the ground with supplementation of concentrates and some minerals. They were identified by their name and fire tattoo.

Animals: Sixty female sheep (4-8 months, weight about $15-20 \mathrm{~kg} \mathrm{b.w.)} \mathrm{were} \mathrm{included}$ in this study. These animals were selected from Beni-Sanad farm (El-Qusya, Assiut Governorate) during summer season (JuneSeptember 2014). The animals were reared under similar feeding systems, management and environmental conditions. All sheep were subjected to careful clinical and laboratory investigations. Sheep were divided into 2 groups (30 each); GI naturally infected with $H$ contortus and GII healthy control.

Positive Haemonchus signs were observed and recorded. Signs included body condition, abnormal behavior, and status of mucus membranes, lymph nodes, gastrointestinal disorders, rectal temperature and feces consistency. No clinical signs were in the control group.

Sampling: From each sheep two blood samples were collected by the jugular vein puncture, in a tube containing EDTA. One was used for hematological studies; and second was centrifuged at 3000rpm for 10 min. Plasma was collected and stored at $20^{\circ} \mathrm{C}$ until processing and preparation of erythrocyte hemolysate. Fecal samples were collected from the rectum of infected and control sheep.

Parasitological examination: Standard flotation sedimentation technique and modified Berman's technique (Coles, 1980) was used 
for fecal samples to ensure that GII was parasites free and to prove that GI infected with $H$. contortus eggs and $3^{\text {rd }}$ stage larvae.

Hematological investigations: Hemogram were determined automatically by automatic blood cell counter (Telldyn 3700, Germany).

Biochemical analysis: Plasma values of Total Free Amino Acids (TFAA), Ceruloplasmin $(\mathrm{CP})$, Copper $(\mathrm{Cu})$ and Iron $(\mathrm{Fe})$ were determined (Rosen, 1957; Houchin, 1958; Kolmer et al, 1951; Bauer, 1984) respectively.

Preparation of erythrocyte hemolysate: Plasma and buffy coats were aspirated; sediment containing blood cells was washed three times by re-suspending in isotonic phosphate-buffered saline, followed by recentrifugation and removal of supernatant fluid and buffy coats. Crude red cells were lysed in nine volumes of ice-cold distilled water to have a $10 \%$ erythrocyte hemolysate. Erythrocyte hemolysate was used to determine protein carbonyl (PC), lipid peroxidation, reduced glutathione (GSH), superoxide dismutase (SOD) and catalase (CAT) (Levine et al, 1990; Placer et al, 1966; Beutler et al, 1963; Misra and Fridovich, 1972; Beers and Sizer, 1952) respectively.

Statistical analysis was performed using Graph Pad Prism 5.0 Software, CA, USA. Parameters were analyzed by ANOVA, and Newman-Keuls test. Data were expressed as means \pm standard and differences between groups by Student t-test. Pearson's correlation $(r)$ and linear regression $\left(\mathrm{R}^{2}\right)$ were done on paired data by GI, significant $\mathrm{p}<0.05$.

Clinically: GI were pale, mucous membranes, accompanied by debilitation, poor body condition (loss weight, wool and projection of ribs) with or without diarrhea.

Hematological findings: A significant reduction ( $\mathrm{P}<0.001)$ was in $\mathrm{Hb}$, RBCs count \& PCV\% in GI as compared with GII, nonsignificant leucocytopenia in both GI \& GII. eosinophils, lymphocytes and monocytes values were significant $(\mathrm{P}<0.05)$, while neutrophil value decreased $(\mathrm{P}<0.05)$ in infected sheep. MCV \& MCHC values significantly decreased $(\mathrm{P}<0.05)$ in infected sheep, indicating a microcytic hypochromic anemia in infested sheep (Tab. 1).

Biochemical changes: infection caused significant increase in erythrocytic lipid peroxidation eMDA and erythrocytic Protein Carbonyl ePC ( $\mathrm{P}<0.01)$ compared to normal ones. By contrast, a significant inhibition of the erythrocytic antioxidant activity of SOD (P <0.01), GSH $(\mathrm{P}<0.01)$, ceruloplasmin (CP) $(\mathrm{P}<0.01)$, Total Iron $(\mathrm{Fe})(\mathrm{P}<0.001)$ and Copper $(\mathrm{Cu})(\mathrm{P}<0.05)$ in plasma was in GII. Significant increase was in erythrocytic catalase activity CAT) \& total free amino acids TFAA ( $\mathrm{P}<0.001)$ in GI (Tab. 2).

Pearson's correlation and regression analysis showed a significant positive correlation between ePC value and eMDA ( $\mathrm{r}=0.470$, $\mathrm{R}^{2}=0.221, \mathrm{P}=0.02$, Fig. 1A), eCAT ( $\mathrm{r}=0.608$, $\mathrm{R}^{2}=0.370, \mathrm{P}=0.001$, Fig. $\left.1 \mathrm{~B}\right)$, TFAA in plasma $\left(\mathrm{r}=0.460, \mathrm{R}^{2}=0.211, \mathrm{P}=0.031\right.$, Fig. 1C) \& Eosinophils\% ( $\mathrm{r}=0.436, \mathrm{R}^{2}=0.190$, $\mathrm{P}=0.047$, Fig. 1D). Concentration of ePC was inversely correlated with values of eSOD ( $r=-0.554, R^{2}=0.307, P=0.039$, Fig. $\left.2 A\right)$, $\mathrm{Hb}\left(\mathrm{r}=-0.438, \mathrm{R}^{2}=0.191, \mathrm{P}=0.041\right.$, Fig. 2B) and $\mathrm{PCV} \%\left(\mathrm{r}=-0.651, \mathrm{R}^{2}=0.423, \mathrm{P}=0.003\right.$, Fig. 2C).

Table 1: Mean values of hematological parameters in healthy and infected sheep:

\begin{tabular}{|l|c|c|}
\hline Parameter & Normal (healthy) & H. contortus infected \\
\hline $\mathrm{Hb}$ g/dl & $12.76 \pm 0.28^{\mathrm{a}}$ & $7.39 \pm 0.54^{\mathrm{b}}$ \\
\hline RBCs count $\left(10^{12} / \mathrm{l}\right)$ & $7.96 \pm 0.16^{\mathrm{a}}$ & $7.76 \pm 0.42^{\mathrm{b}}$ \\
\hline PCV\% & $35.99 \pm 2.19^{\mathrm{a}}$ & $24.41 \pm 0.95^{\mathrm{b}}$ \\
\hline WBCs count K/ul & $7.37 \pm 0.50^{\mathrm{a}}$ & $6.83 \pm 0.43^{\mathrm{a}}$ \\
\hline Eosinophils K/ul & $0.078 \pm 0.02^{\mathrm{a}}$ & $0.31 \pm 0.05^{\mathrm{b}}$ \\
\hline Lymphocytes K/ul & $1.72 \pm 0.12^{\mathrm{a}}$ & $2.30 \pm 0.18^{\mathrm{b}}$ \\
\hline Neutrophil K/ul & $4.80 \pm 0.33^{\mathrm{a}}$ & $2.95 \pm 0.37^{\mathrm{b}}$ \\
\hline Monocytes & $0.73 \pm 0.08^{\mathrm{a}}$ & $1.29 \pm 0.11^{\mathrm{b}}$ \\
\hline MCV fl & $39.85 \pm 1.2^{\mathrm{a}}$ & $32.11 \pm 1.9^{\mathrm{b}}$ \\
\hline MCHCg/dl & $35.92 \pm 0.81^{\mathrm{a}}$ & $29.99 \pm 1.25^{\mathrm{b}}$ \\
\hline
\end{tabular}


Table 2: Mean values of biochemical parameters in healthy and infested sheep:

\begin{tabular}{|l|c|c|}
\hline Parameter & Normal (healthy) & H. contortus infected \\
\hline MDA nmole/mg Hb & $31.45 \pm 0.17^{\mathrm{a}}$ & $43.90 \pm 5.51^{\mathrm{b}}$ \\
\hline $\mathrm{PC} \mu \mathrm{mole} / \mathrm{mg} \mathrm{Hb}$ & $0.67 \pm 0.04^{\mathrm{a}}$ & $1.12 \pm 0.13^{\mathrm{b}}$ \\
\hline Catalase U/mg Hb & $7.99 \pm 0.39^{\mathrm{a}}$ & $10.65 \pm 0.53^{\mathrm{b}}$ \\
\hline Ceruloplasmin mg/g protein & $4.96 \pm 0.25^{\mathrm{a}}$ & $4.16 \pm 0.14^{\mathrm{b}}$ \\
\hline $\mathrm{SOD} \mathrm{U/mg} \mathrm{Hb}$ & $2.46 \pm 0.17^{\mathrm{a}}$ & $1.80 \pm 0.11^{\mathrm{b}}$ \\
\hline $\mathrm{GSH} \mathrm{mg/mg} \mathrm{Hb}$ & $1.01 \pm 0.05^{\mathrm{a}}$ & $0.77 \pm 0.05^{\mathrm{b}}$ \\
\hline $\mathrm{TFAA} \mu \mathrm{g} / \mathrm{mg}$ protein & $4.50 \pm 0.15^{\mathrm{a}}$ & $6.24 \pm 0.31^{\mathrm{b}}$ \\
\hline $\mathrm{Fe} \mu \mathrm{g} / \mathrm{dl}$ & $228.8 \pm 10.7^{\mathrm{a}}$ & $110.3 \pm 21.4^{\mathrm{b}}$ \\
\hline $\mathrm{Cu} \mu \mathrm{g} / \mathrm{dl}$ & $50.08 \pm 9.00^{\mathrm{a}}$ & $23.80 \pm 2.61^{\mathrm{b}}$ \\
\hline
\end{tabular}

${ }^{\mathrm{a}, \mathrm{b}}$ Values in same row with unlike descriptive superscript letters =significantly different $(P<0.05)$.

\section{Discussion}

Few literatures dealt with gastrointestinal nematodes effect on the oxidative stress parameters and antioxidant defenses in sheep (Dede et al, 2002) in spite of the exceeded exposure of sheep to $H$. contortus parasite now and later which considered amongst the main parasitic infestations in Egypt. Anemia is a characteristic feature of nematodiasis in sheep. The reported microcytic hypochromic (Iron deficiency) anemia in infected sheep agreed with Qamar and Maqbool (2012). Reduction of serum iron level in infected sheep could be attributed to expanded erythropoiesis to compensate for blood loss leading to depletion of iron stores. These findings agreed with Albers et al (1990).

Oxidative stress arises when there is an imbalance between radical-generating and radical-scavenging activity; it may therefore cause an increase in the formation of oxidation products (Gutteridge, 1995). The excessive production of reactive oxygen species (ROS) resulted from the excitation of $\mathrm{O}_{2}$ to form singlet oxygen or from the transfer of one, two or three electrons to $\mathrm{O}_{2}$ to form a superoxide radical $\left(\mathrm{O}_{2}{ }^{-}\right)$, hydrogen peroxide $\left(\mathrm{H}_{2} \mathrm{O}_{2}\right)$ or a hydroxyl radical $(\mathrm{HO})$, respectively (Urban-Chmiel et al, 2009). The most sensitive part of the cell towards the action of ROS, primarily the hydroxyl radical, was polyunsaturated fatty acids (PUFA) of cell membranes. The end product of PUFA destruction during lipid peroxidation was malondialdehyde, so the increase of its concentration in tissues or biological fluids was considered as an indicator of increased production of free radicals and oxidative stress
(Marnett, 1999). Dede et al. (2000) determined that the MDA level increased significantly in Akkaraman sheep infested with Fasciola spp., Trichostrongylidae, and Eimeria spp. Also, Simseket al. (2006) reported MDA level increased with Dicrocoelium dendriticum and Strongyloides papillosus infection of sheep respectively. The data showed thatpronounced increase in MDA values in infected sheep with $H$. contortus. This might be due to oxidative damage in the cell membrane which possibly resulted from overproduction of free radicals.

Protein oxidation by ROS was associated with the formation of many different kinds of inter- and intra-protein cross-linkages, including those formed by addition of lysine amino groups to the carbonyl group of an oxidized protein (Valko et al, 2006). In mammalian system direct damage to proteins or chemical modification of amino acids in proteins during oxidative stress gave rise to protein carbonyls (PC) (Stadtman and Berlett, 1998). The usage of PC as bio-markers of oxidative stress has some advantages in comparison with the measurement of other oxidation products because of the relative early formation and the relative stability of carbonylated proteins (Dalle-Donne et al, 2003). The highly reactive hydroxyl radical $(\mathrm{OH} \bullet)$ was generated by high concentration of $\mathrm{H}_{2} \mathrm{O}_{2}$ to be responsible for the formation of PC (Oliver, 1987). There were no reports available about protein oxidation in gastrointestinal nematodiasis of sheep. However, Dimitrijevi'c et al. (2012) reported that the level of PC was increased with the intensity of the Strongyloides papillosus infection in 
sheep, reaching the maximum value in the group with the highest degree of infestation. In the present study, the increased erythrocytic PC (ePC) in GI suggested a rise in the oxidative damage of both cell membrane protein and hemoglobin confirming an enhancement of erythrocytic free radical overproduction in parasitized sheep. So, nematodiasis in sheep caused excessive release of hydroxyl free radical rather than hydrogen peroxide. The present data showed a significant decrease of erythrocytic reduced glutathione (GSH) acted as a substrate in detoxification of peroxides such as hydrogen peroxide: $\mathrm{H}_{2} \mathrm{O}_{2}$ (Rahman and MacNee, 1999).

The presence of parasites in the host spurs defense mechanisms. The first, unspecific line of defense represented activated macrophages (Saleh, 2008). Catalase (CAT) facilitated the removal of $\mathrm{H}_{2} \mathrm{O}_{2}$, metabolized to molecular oxygen $\left(\mathrm{O}_{2}\right)$ and water (Van der Oost et al, 2003). Baghshani et al. (2011) assigned that increased activity of CAT caused by parasitic infestation of sheep was due to overproduction of $\mathrm{H}_{2} \mathrm{O}_{2}$. The current data, in agreement with the previous results, showed increased activity of CAT and may point out to a moderate not severe intensity of parasitic infestation or that the stage of infestation was early which counteracted by the host defense mechanism to overcome the overproduction of $\mathrm{H}_{2} \mathrm{O}_{2}$. This concept was in harmony with the depletion of erythrocytic superoxide dismutase activity (eSOD) shown in the present study. eSOD activity had been proposed as the main reductant of oxygen in mitochondrial membranes (Inoue et $a l, 2003)$ and its activity increased in the case of a larger production of $\mathrm{O}_{2}^{-}$or inhibited in the case of an increased production of $\mathrm{H}_{2} \mathrm{O}_{2}$, which raised by enzymatic oxidation of the radical superoxide anion (Halliwell and Gutteridge, 1999). Reduced glutathione (GSH), a tripeptidethiol, is an important antioxidant protein enzyme, as well as a cofactor for various antioxidant enzymes (Kidd, 1997). Reznick and Packer (1994) found that Oxidative modification of pro- teins may lead to the structural alteration and functional inactivation of many enzyme proteins including GSH and SOD. The current data exhibited that both GSH and SOD depletions may be at least in part to the excess protein carbonyl accumulation which was probably concomitant with increased production of $\mathrm{H}_{2} \mathrm{O}_{2}$.

Ceruloplasmin $(\mathrm{CP})$ is the main cupremic determinant in plasma and acts as an extracellular scavenger of free radicals, thus it may protect the cells against ROS (Saenko et al, 1994). Ceruloplasmin activity and the serum or plasma copper concentration decreased with nutritional copper depletion of ruminants (Blakley and Hamilton, 1985). Frandsen (1982) reported that blood copper levels were depressed in ruminants infested with nematodes. Most of the works reported on the relationship between endoparasitism and copper deficiency had been based on the oral copper supplementation (Adogwa et al, 2005). The previous authors added that gastrointestinal parasites affected copper metabolism probably by interference with $\mathrm{Cu}$ absorption from gastrointestinal tract. The present data explained that both plasma $\mathrm{CP}$ and $\mathrm{Cu}$ ions were significantly decreased. Mulcahy et al. (2004) reported that H. contortus increased $\mathrm{pH}$ value of abomasums. So, it could be suggested that $H$. contortus affected copper metabolism perhaps due to interference with copper absorption from gastrointestinal tract by increasing $\mathrm{pH}$ of the abomasal environment. So, infection caused $\mathrm{Cu}$ deficiency in blood and led to reduction in plasma ceruloplasmin.

A reduction of plasma protein concentrations (Wallace et al, 1996) was due to blood loss, hemorrhagic gastritis and leakage of proteins to gastric lumen caused disruption of intercellular unions and increased gut permeability (Baker et al, 2003). Proteases facilitate the invasion of host tissues, aid in the digestion of host proteins and help parasites evade the host immune response. Proteases encompass a broad class of hydrolytic enzymes that play essential roles in digestive 
processes of proteins (Williamson et al, 2003) leading to protein degradation and increased formation of plasma total free amino acids (TFAA). Determination of TFAA provided useful marker of total pool of each free amino acid and protein metabolism (Canepa et al, 2002). Infected sheep had lower food intake (Vervelde et al, 2001). Their malnutrition caused increase in protein breakdown and increased plasma TFAA level to support gluconeogenesis (Almeida et al, 2006). The present study showed a significant increase in plasma TFAA in infected sheep, such finding perhaps due to increased protein degradation through the action of proteases enzyme and muscle breakdown which probably due to activation of gluconeogenesis as a compensatory mechanism and/or due to decreased both uptake and absorption of nutritional amino acids caused by malnutrition and increased abomasal $\mathrm{pH}$ respectively. The significant rise of plasma TFAA might be attributed to an increase in free hemoglobin released probably from the exploded RBCs after filling with $\mathrm{H}_{2} \mathrm{O}_{2}$ due to severe depletion of eGSH. Anemia led to hypoxia (Chang and Stevenson, 2004) and hypoxia, increased $\mathrm{Hb}$ autoxidation augments superoxide production in RBCs led to RBCs release of $\mathrm{H}_{2} \mathrm{O}_{2}$ (Kiefmann et al, 2008). RBCs contain a large proportion of free amino acids in total blood (Felig et al, 1979).

In this study, non-significant decrease in total leucocytes with marked eosinophilia, monocytosis and lymphocytosis in blood of infected sheep. Rahman and Collins (1990) went with the present results, stated that infection with $H$. contortus did not lead to significant changes in total white cell counts with marked eosinophilia. Eosinophils produce and store many secondary granule proteins prior to their exit from the bone marrow, after maturation, eosinophils circulate in blood and migrate to inflammatory sites in tissues, or to sites of helminthes infection in response to chemokines and certain leukotriens (Wagner et al, 2007). Nebiat et al.
(2012) found that Intestinal infection with, Trichinella spiralis, induced a pronounced eosinophilia and revealed benefit and protective role of eosinophils in the host by preserving the antigenic stimulus for a Th2 response that prevents reinfection of the intestine. The authors added that eosinophils may support parasite growth and survival by promoting accumulation of $\mathrm{Th} 2$ cells and preventing induction of iNOS in macrophages and neutrophils. However, eosinophil peroxidase forms reactive oxygen species that promote oxidative stress in the target, causing cell death by apoptosis and necrosis (Rothenberg and Hogan, 2006). Eosinophil activation in vivo resulted in eosinophil peroxidase (EPO) release and oxidative damage to proteins through bromination of tyrosine residues (Mitra et al, 2000). Meeusen and Balic (2000) found that eosinophils killed only infective larval stages of most helminthes. Hohenhaus et al. (1999) in $H$. contortus infected sheep, found a strong association between high eosinophil leucocyte counts and retention of normal levels of circulating eosinophil leucocytes with resistance to stress. The present result assumed that eosinophilia responded to haemonchosis was an immunological regulator against any excessive harmful parasitic effect on the host. Furthermore, the obtained data showed that there was a positive correlation of $\mathrm{ePC}$ with eosinophilia suggesting a recruiting role of eosinophils to curtail magnification of oxidative damage extent in $H$. contortus infected sheep through their resisting effect against stress due to parasitosis.

The current study showed negative correlation of ePC with eSOD, $\mathrm{Hb}$ and PCV due to protein oxidation that led to injury of functional proteins in hemoglobin, erythrocytic membrane and enzymatic antioxidant SOD led to drop in them. Reznick and Packer (1994) reported that oxidative modification of proteins led to structural alteration and functional inactivation of many enzyme proteins. Another cause of anemia in infected sheep rose in ePC and protein degrada- 
tion. There was positive correlation of erythrocytic PC with plasma TFAA and eMDA.

\section{Conclusion}

The outcome results showed that sheep haemonchosis was accompanied by protein oxidation and a state of oxidative stress that led to disturbances in protein synthesis and to the pathogenesis of the disease and due to inappetance, gastrointestinal losses of protein and increased plasma TFAA. Infection decreased availability for growth, milk, and meat and wool production in sheep.

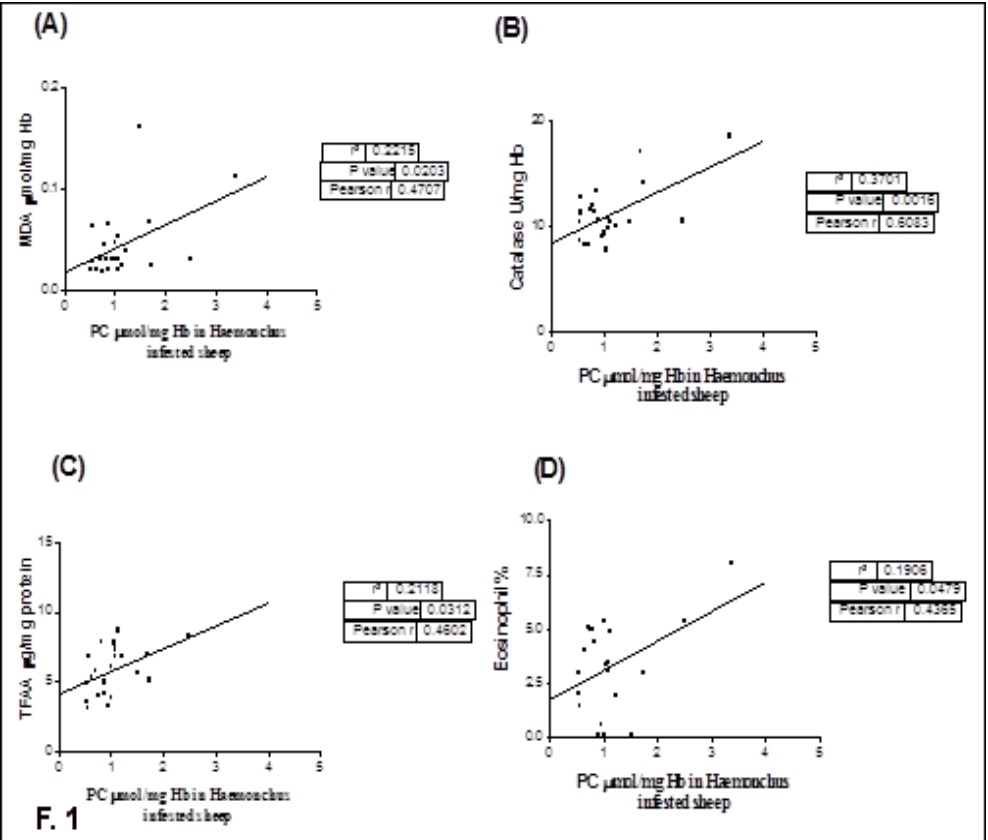

Fig. 1: Correlation of erythrocytic Protein Carbonyl (ePC) values with erythocytic lipid peroxidation (eMDA; A), erythrocytic Catalase (eCAT; B), plasma Total Free Amino Acids (TFAA; C) and Eosinophil \% D in Haemonchus contortus infected sheep.

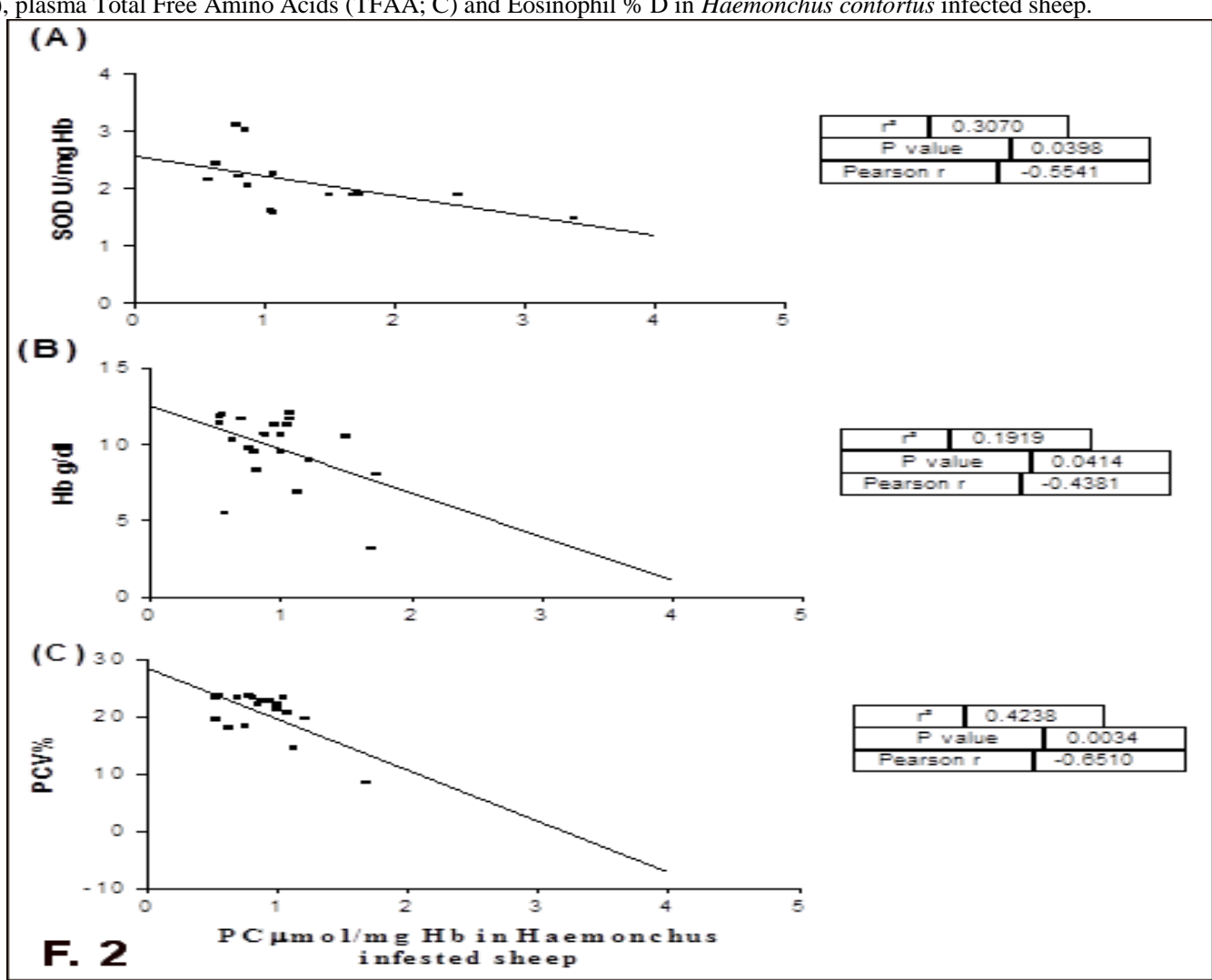

Fig. 2: Correlation of erythrocytic Protein Carbonyl (ePC) values with erythrocytic Superoxide dismutase(eSOD; A), Blood Haemoglobin (Hb; B) and Blood PCV\% (PCV\%; C). in Haemonchus contortus infected sheep. 


\section{References}

Adogwa, A, Mutani, A, Ramnanan, A, Ezeokoli, C, 2005: The effect of gastrointestinal parasitism on blood copper and hemoglobin levels in sheep. Can. Vet. J. 46:1017-21.

Albers, GAA, Gray, GD, Le Jambre, LF, Barger, IA, Barker, JSF, 1990: The effect of $H$. contortus infection on haematological Parameters in young Merino sheep and its significance for productivity Animal Product. 50:99-109.

Almeida, AM, Schwalbach, LMJ, Waal, HO, Greyling, JPC,Cardoso, LA, 2006: Plasma free amino acid profiles of Boer goat bucks asinfluenced by two feeding regimens. Proc. $42^{\text {nd }}$ Cong. South African Society for Animal Science.

Baghshani, H, Razmi, GR,Yaghfouri, S, Dezaki, AA, 2011: Status of some oxidative stress biomarkers in sheep naturally infected with theileriosis. Roavs. 1,8:499-504.

Baker, RL, Nagad, S, Rodriguez-Zas, SL, Southey, BR, Audho, JO, et al, 2003: Resistance and resilience to gastro-intestinal nematode parasites and relationships with productivity of Red Massai, Dorper and Red Massai X Dorper crossbred lambs in the sub-humid tropics. Anim. Sci. 76:119-36.

Bauer, JD, 1984: Haemoglobin, porphyrin, and iron metabolism. In: Kaplan LA, Pesce AJ, ed. Clinical Chemistry, Theory, Analysis, and correlation. ST. Louis: Mosby Company.

Beal, MF, 2002: Oxidatively modified proteins in aging and disease. Free Rad. Biol. Med. 32, 9:797-803.

Beers, Jr, RF, Sizer, IW, 1952: A spectrophotometric method for measuring the breakdown of hydrogen peroxide by catalase. J. Biol. Chem. 195:133-40.

Beutler, E, Duron, O, Kelly, BM, 1963: Improved method for the determination of blood glutathione. J. Lab. Clin. Med. 61:882-8.

Blakley, BR, Hamilton, DL, 1985: Ceruloplasmin as an indicator of copper status in cattle and sheep. Can. J. Comp. Med. 49:405-8.

Bordoloi, G, Jas, R, Ghosh, JD, 2012: Changes in the haemato-biochemical pattern due to experimentally induced haemonchosis in Sahabadi sheep. J. Parasit. Dis. 36, 1:101-5.

Canepa, A, Filho, JCD, Gutierrez, A, Carrea1, A, Forsberg, AM,et al, 2002: Free amino acids in plasma, red blood cells, polymorphonuclear leukocytes, and muscle in normal and uraemic children. Nephrol. Dial.Transplant. 17: 413-21.

Chang, KH, Stevenson, MM, 2004: Malarial anaemia: mechanisms and implications of insufficient erythropoiesis during blood-stage malaria. Int. J. Parasitol. 34, 13/14:1501-16.

C'imen, MYB, 2008: Free radical metabolism in human erythrocytes. Clin.Chim.Acta. 390, 1-11. Coles, EH, 1980: Veterinary Clinical Pathology, third ed. Saunders Co, Philadelphia.

Dalle-Donne, I, Rossi, R, Giustarini, D, Milzani, A, Colombo, C, 2003: Protein carbonyl groups as biomarkers of oxidative stress. Clinica.Chimica.Acta. 329:23-38.

Dede, S, Deger, Y, Deger, S, Alkan, M, 2000: Determination of the status of lipid peroxidation and antioxidants in sheep infected with certain endoparasites (Fasciola spp., Trichostronglidae spp., Eimeria spp.). Acta.Parasit.Turc. 24:190-3.

Dede, S, Deger, Y, Alkan, M, Cemek, M, 2002: Oxidation products of nitric oxide and the concentration of antioxidant vitamins in parasitized goats. Acta. Vet. Brno. 71:1-5.

Dimitrijevi'c, B, Borozan, B, Kati'c-Radivojevi'c, S, Stojanovi'c, S, 2012: Effects of infection intensity with Strongyloides papillosus and albendazole treatment on development of oxidative/nitrosative stress in sheep. Vet. Parasitol. 186:364-75.

Felig, P, Wahren, J, Räf, L, 1973: Evidence of inter-organ amino acid transport by blood cells in human. Proc. Natl. Acad. Sci. USA. 70, 6: 1775-9.

Frandsen, JC, 1982: Effects of concurrent subclinical infections by coccidian (Eimeria chistenseni) and intestinal nematodes (Trichostrongylus colubriformis) on apparent nutrient digestibilities, serum copper and zinc, and bone mineralization in the pigmy goat. Am. J. Vet. Res. 43:1951-3.

Gutteridge, JMC, 1995: Lipid peroxidation and antioxidants as biomarkers of tissue damage. Clin. Chem. 41:1819-28.

Halliwell, B, 1996: Antioxidants in human health and disease. Ann.Rev. Nutr. 16:33-50.

Halliwell, B, Gutteridge, JMC, 1999: Free Radicals in Biology and Medicine, $3^{\text {rd }}$ ed. Oxford University Press.

Harvey, JW, 1997: The erythrocyte: Physiology, Metabolism and Biochemical disorders. In: Clinical Biochemistry of Domestic Animals. $5^{\text {th }}$ 
Edition. Kaneko, J.J., Harvey, J.W. (Eds.), M.L.Bruss Academic press, London.

Hayat, CS, Hussain, SM, Iqbal, Z, Hayat, B, Akhtar, M, 1996: Effect of parasitic nematodes on haematology and productivity of sheep. Pak. Vet. J. 16, 2:81-3.

Hohenhaus, MA, Josey, MJ, Dobson, C, Outteridge, PM, 1998: The eosinophil leucocyte, a phenotypic marker of resistance to nematode parasites, is associated with calm behaviour in sheep. Immunol Cell Biol. 76, 2:153-8.

Houchin, J, 1958: Methods of determination of serum ceruloplasmin level. Am. J. Biochem. 13: 41-8.

Inoue, M, Sato, EF, Nishikawa, M, Park, AM,Kira, Y, et al, 2003: Mitochondrial generation of reactive oxygen species and its role in aerobic life. Curr. Med. Chem. 10, 2495-505.

Kidd, PM, 1997: Glutathione: Systemic protectant against oxidative and free radical damage. Altern. Med. Re. 2:155-76.

Kiefmann, R, Rifkind, JM, Nagababu, E, Bhattacharya, J, 2008: Red blood cells induce hypoxic lung inflammation. Blood 111, 10: 5205-14.

Kolmer, JA, Spandling, EH, Robinson, HW, 1951: Approved Laboratory Techniques, $5 \mathrm{t}^{\mathrm{h}} \mathrm{edn}$. Appleton: Century Crafts, Inc., New York.

Kurata, M, Suzuki, M, Agar, NS, 1993: Antioxidant systems and erythrocyte lifespan in mammals. Comp.Biochem. Physiol. B. 106:47787.

Levine, RL, Garland, D, Oliver, CN, Amici, A, Climent, I, et al, 1990: Determination of carbonyl content in oxidatively modified proteins. Methods Enzymol. 186:464-78.

Lykkesfeldt, J, Svendsen, O, 2007: Oxidants and antioxidants in disease: oxidative stress in farm animals. Vet. J. 173:502-11.

Marnett, LJ, 1999: Lipid peroxidation-DNA damage by malondialdehyde. Mutat. Res. Fundam. Mol. Mech. Mutagen. 424:83-95.

Meeusen, EN, Balic, A, 2000: Reviews, Do Eosinophils have a Role in the Killing of Helminth Parasites?.Parasitol.Today. 16, 3:95-101.

Mir, AR, Chishti, MZ, Zarger, MA, Tak, H, Ganie, SA, 2007: clinicopathological changes in sheep experimentally infected with Haemonchus contortus. World J. Agric. Sci. 3, 5:562-6.

Misra, HP, Fridovich, I, 1972: The role of superoxide anion in the auto oxidation of epinephrine and a simple assay for superoxide dismutase. J. Biol. Chem. 247:3170-4.
Mitra, SN, Slungaard, A, Hazen, SL, 2000: Role of eosinophil peroxidase in the origins of protein oxidation in asthma. Redox Rep. 5:21524.

Mulcahy, G, O Neill, S, Donnelly, S, Dalton, JP, 2004: Helminths at mucosal barriers-interaction with the immune system. Adv. Drug Deliv. Rev. 56: 853-68.

Nebiat, GG, An drew, RM, Fabre, V, Gagliardo, LF, Lee, NA, et al, 2012: Eosinophils preserve parasitic nematode larvae by regulating local immunity. J. Immunol. 188, 1:417-25.

Oliver, CN, 1987: Inactivation of enzymes and oxidative modification of proteins by stimulated neutrophils, Arch. Biochem. Biophys. 253:62-8.

Pal, BK, Kulkarni, S, Bhandari, Y, Balaji, B, Ganesh, K, et al, 2005: Lymphatic filariasis: Possible pathophysiological nexus with oxidative stress. Trans. Roy. Soc. Trop. Med. Hyg. 100:650-5.

Placer, ZA, Cushman, LL, Johnson, BC, 1966: Estimation of product of lipid peroxidation (malonyldialdehyde) in biochemical systems. Anal.Biochem. 16, 359-64.

Qamar, MF, Maqbool, A, 2012: Biochemical studies and serodiagnosis of Haemonchosis in sheep and goats. J. Anim. Plant Sci. 22, 1:32-8.

Rahman, WA, Collins, GH, 1990: Changes in live weight gain, blood constituent and worm egg output in goats artificially infected with a sheep derived strain of $H$. contortus. Brit. Vet. J. 146, 6:543-50.

Rahman, I, MacNee, W, 1999: Lung glutathione and oxidative stress: implications in cigarette smoke-induced airway disease. Am. J. Physiol. 277, 6:L1067-88.

Reznick, AZ, Packer, L, 1994: Oxidative damage to proteins: spectrophotometric methods for carbonyl assay. Meth. Enzymol. 233:357-63.

Ridnour, LA, Isenberg, JS, Espey, MG, Thomas, DD, Roberts, DD, et al, 2005: Nitric oxide regulates angiogenesis through a functional switch involving thrombospondin-1. Proc. Natl. Acad. Sci. U. S. A. 102:13147-52.

Rosen, H, 1957: A modified ninhydrin colorimetric analysis for amino acids. Biochem. Biophys. 67:10-5.

Rothenberg, M, Hogan, S, 2006: The eosinophil. Ann. Rev. Immunol. 24, 1:147-74.

Saenko, EL, Yaropolov, AI, Harris, ED, 1994: Biological functions of caeruloplasmin expressed through copper-binding site and cellular receptor. J. Trace Elem. Exp. Med. 7, 69-88. 
Saleh, MA, 2008: Circulating oxidative stress status in desert sheep naturally infected with Fasciola hepatica. Vet. Parasitol. 154:262-9.

Simsek, S, Yuce, A, Utuk, AE, 2006: Determination of serum malondialdehyde levels in sheep naturally infected with Dicrocoelium dendriticum. Furat Üniversitesi Sağlı Bilimleri Dergisi (Veteriner). 20:217-20.

Soulsby, EJL, 1982: Helminths, arthropods and protozoa of domesticated animals, 7 th edn. The English Language Book Society and Bailliere, Tindall.

Stadtman, ER, Berlett, BS, 1998: Reactive oxygen mediated protein oxidation in aging and disease. Drug Met. Rev. 30:225-9.

Stadtman, ER, Oliver, CN, Starke-Reed, PE, 1991: Implication of metalcatalyzed oxidation of enzymes in aging, protein turnover, and oxygen toxicity. Korean. J. Biochem. 23:49-54.

Upcroft, P, Upcroft, JA, 2001: Drug targets and mechanisms of resistance in the anaerobic protozoa. Clin. Microbiol. Rev.14:150-64.

Urban-Chmiel, R, Kankofer, M, Wernicki, A, Albera, E, Puchalski, A, 2009: The influence of different doses of $\alpha$-tocopherol and ascorbic acid on selected oxidative stress parameters in vitro culture of leukocytes isolated from transported calves. Livestock Sci. 124:89-92.
Urquhart, GM, 1996: Veterinary Parasitology. Blackwell Science, Cambridge, London, United Kingdom.

Valko, M, Rhodes, CJ, Moncol, J, Izakovic, M, Mazur, M, 2006: Free radicals, metals and antioxidants in oxidative stress-induced cancer. Chem. Biol. Interact. 160:1-40.

Van der Oost, R, Beyer, J, Vermeulen, NPE, 2003: Fish bioaccumulation and biomarkers in environmental risk assessment: a review. Environ. Toxicol. Pharmacol. 13:157-49.

Vervelde, L, Kooyman, FNJ, Van Leeuwen, MAW, Schallig, HDFH, Mckellar, A, et al, 2001: Age related protective immunity after vaccination with Haemonchus contortus excretory/secretory proteins. Parasitol. Immunol. 23: 419-26.

Wagner, LA, Christensen, CJ, Dunn, DM, 2007: EGO, a novel, non-coding RNA gene, regulates eosinophil granule protein transcript expression. Blood 109, 12:5191-8.

Wallace, DS, Bairden, K, Duncan, JL, Fishwick, G, Gill, M, et al, 1996: Influence of soyabean meal supplementation on the resistance of Scottish Blackface lambs to haemonchosis. Res. Vet. Sci. 60:138-43.

Williamson, AL, Brindley, PJ, nox, DP, Hotez, PJ, Loukas, A, 2003: A digestive proteases of blood feeding nematodes. Trends Parasitol. 19, 9:417-23. 